\title{
The Natansons as an Embodiment of the Evils of Assimilation In the Anti-Semitic Weekly Rola
}

\author{
Agnieszka Friedrich \\ (University of Gdańsk, Faculty of Polish Philology) \\ e-mail: afriedrich@univ.gda.pl
}

Key words: anti-Semitism, assimilation, the image of the Jew, Natanson family, Jan Jeleński, Rola

\begin{abstract}
Rola was the first periodical in Poland of an unequivocally anti-Semitic profile. An essential element of its ideological programme was combatting Jewish assimilation. According to Rola, processes of assimilation were responsible for generating a new type of Jew - liberal, assimilated and unprincipled - and therefore much more perilous to Polish national interests than the model of a traditional, Orthodox Jew.
\end{abstract}

Soon, the abstractly delineated model of the modern Jew assumed a concrete figure in the pages of Rola. The members of the Warsaw Natanson family became an embodiment of the evils of assimilation. They were charged with preparation of the so-called 'stock exchange memorandum', which for the Anti-Semites was proof of Jewish struggle for economic supremacy in the Kingdom of Poland; exploitation was tracked down in factories belonging to the Natansons, as were their supposed attempts at disingenuous take-overs of public goods or their domination in Polish social institutions under false slogans of "unity" and "fraternity." The younger members of the family were accused of clandestine take-overs of the Christian press and demoralisation of Polish society with publications of "free-thinking' and unprincipled brochures under the banner of the "Jewish-Heathen torch".

With respect to the Natansons' social activity, Rola employed the term 'company', unequivocally suggesting that the activity had, as a matter of fact, nothing to do with public good, but rather was pure enterprise. In addition, the 'business' was defined not only in economic, but also in social and ideological terms.

In their fight against the Natansons, Rola also resorted to peculiar linguistic devices. For example, the name 'natansonade' was frequently used to describe all undertakings of the loathed family, which Rola deemed to be obscure and deceptive. In turn, in their most aggressive attacks, where the magazine went beyond acceptable limits of criticism and debate, into realms of insinuation or confabulation, Rola made eager use of the fictitious name of 'Panthersohns', which its readers were supposed to identify with the Natansons. 
The Warsaw Rola weekly was established by Jan Jeleński in 1883 as the first periodical in Poland of an unequivocally Anti-Semitic profile. ${ }^{1}$ From its inception, a significant, if not the most essential, element of its programme was combatting assimilation. Already in the first months of the new weekly's publication, the programme was explicitly expounded by Rola's leading columnist, Teodor Jeske-Choiński, who wrote:

We are repelled by the so-called "civilised" Jew, believing in nothing, safe gold and carnal indulgence; repelled by a liberal sloganeer, thrusting about his humanitarian ideas, as he sees fit; repelled by every colourless, indifferent man, living a life of the beasts of prey.

\section{And further:}

If you are a Jew, be one! The uncouth Orthodox Jew is dearer to us than the civilised zero, since the former believes in something, is someone, while the latter proffers no guarantee. He will sell you for gesheft, will swindle everything away, as he is a supporter of ruthless, vile utilitarianism. If you are Jews, be them... Our only purpose is that you do not swallow us, do not subdue us in our own land. ${ }^{2}$

Three years later, in 1886, the above-sketched blueprint of the unprincipled, liberal, assimilated Jew assumed - in the eyes of Rola columnists - a concrete shape. From that point on, the most glaring embodiment of the evils of assimilation, their symbol, for the 'Rolars' ['rola' in Polish means both a 'role', or 'position', and a 'land', or 'farmland'], became members of the Warsaw Natanson family. The Natansons belonged among the leading representatives of the milieu of assimilated Polish Jews: industrialists and financiers, lawyers, physicians, academics, publishers came from the family. In the 1880s, Antoni Zaleski commented on the family: "The Natansons... have, among our Jewry, a halo of gravity, and Jakub has even been referred to as the pope of Juda."3

The aforementioned Jakub Natanson passed away in 1884, in an aura of universal respect. Even Rola, as personified by its editor-in-chief and publisher, did not decry his achievements, both in the academic and the financial domain. Nonetheless, Jeleński could not come to terms with the fact that "the conservative and thoroughly Christian, Polish society were to go as far as to seek 'role models' for itself in such spheres." ${ }^{4}$ His reaction is highly symptomatic, clearly suggesting Jeleński’s and his magazine’s anti-assimilationist ideological profile.

Rola's anti-assimilationist, or, essentially, anti-Semitic position found surprising and painstakingly harnessed fuel generated by a famed event, participants in which

\footnotetext{
${ }^{1}$ Recent discussions of Rola's significance in the development of anti-Semitism in Poland include: Weeks (2006): 87-99; Domagalska (2015), passim, see esp. 48-56; Moszyński (2017), passim, see esp. $177-254$.

${ }^{2}$ Pancerny [Teodor Jeske-Choiński], 'Na posterunku', Rola, no. 19, 1883: 9.

${ }^{3}$ Zaleski 1971: 319. The Natansons' leading role in furthering economic and social life in the Kingdom of Poland was also discussed in 1926 by Adolf Peretz (under the pseudonym 'Ignotus'), who counted them among the most significant plutocratic families of Warsaw. Ignotus, 2008: 99-105.

${ }^{4}$ Kamienny (Jan Jeleński), 'Na posterunku', Rola, no. 20, 1885: 236.
} 
were, among others, representatives of the Natanson family. Namely, three Natansons Henryk, Ludwik, and Kazimierz - took part in the preparation of a notorious report of the Stock Exchange Committee in Warsaw [Komitet Giełdowy w Warszawie], officially signed by Jan Bloch and Henryk Natanson, and designated for Russian authorities. The report, commonly known as 'the stock-exchange memorandum', albeit originally unintended for publication, was nonetheless partly divulged to the public by the already conservative-leaning Niwa magazine. This gave rise to a scandal of far-reaching consequences for the understanding of the so-called 'Jewish problem' in Poland and the incitement of anti-Semitic moods. ${ }^{5}$

The main purpose of the authors and signatories of the memorandum was to demonstrate beneficial results of the emancipatory acts of 1862, both for the Jewish population and for the totality of socio-economic life in the Congress Kingdom. The aim was expressed, for instance, by such an excerpt from the document:

The above brief sketch is an analysis of a factual social truth that Jews occupy a leading position in the entirety of economic life of the country insofar as the central place in economic relations belongs to the capital and the productive mediation between production and the market. ${ }^{6}$

These kinds of statements provoked a heated discussion in the pages of the Warsaw press. According to the above-quoted Niwa, extolling merits of the Jews was performed at the expense of the non-Jewish inhabitants of the country, Poles in particular. Their editorial on the memorandum claims that "[it] is, indeed, nothing but a wholly unmerited apology of the Jewry, brought out against a dark background of the natively local element [original italics; a quotation of the term appearing in the memorandum - A.F.], being put to the pillory of indolence, fecklessness, slothfulness, crudity of customs and the like." Their position was unreservedly supported by the anti-Semitic Wiek, but also by the moderate Stowo ${ }^{8}$ which discussed the memorandum as "a document which errs on the side of tactlessness, ignorance of local conditions, and disregard for the natively local element." Even the writer, Bolesław Prus, generally well-disposed to assimilation, accused the memorandum of a substantial partiality of opinion, pointing out the omission of sources of economic growth in the Kingdom of Poland other than the emancipation of Jews. ${ }^{10}$

The controversial document was, of course, immediately taken up by Rola to intensify their anti-Semitic attacks. One of their columnists, Franciszek Olszewski, claimed that the document, denouncing Polish society to Russian authorities, referred to throughout

\footnotetext{
${ }^{5}$ The memorandum is discussed in, e.g.: Eisenbach 1983. For controversies produced by the memorandum and its anti-Semitic reception, see, e.g.: Jaszczuk 1986: 239-247; Weeks 2006: 96-99; Moszyński 2017: 256-259.

${ }^{6}$ Quoted after: Eisenbach 1983: 278; see also: 271.

${ }^{7}$ Nie tędy droga. Memoriat Warszawskiego Komitetu Giełdowego w sprawie żydowskiej, „Niwa”, no. 276, 1886: 836 .

${ }^{8}$ Cf. Szweykowski 1960: 561-562.

${ }^{9}$ Ibid:: 562 .

${ }^{10}$ For Bolesław Prus' attitude towards the memorandum see Friedrich 2008: 125-132.
} 
as "the Jewish manifesto", offered proof that emancipation had been a mistake. Subsequently, dubbing the memorandum "venom-spiked spittle of Semitism", he concluded that its authors attempted to prove that "the natively local population [original emphasis] can only be made content by the Jews; that owing to its innate faults, only in their hands can it be a decent raw material, a muck for the soil of their activities."11

Thus, the stock-exchange memorandum became, for the Rola milieu, proof of the erroneousness of the assimilatory path, while the Natansons' contribution to the document's preparation became a pretext for intensifying attacks on members of the fami1y. ${ }^{12}$ Several years later, Jan Jeleński, Rola's editor-in-chief, reporting on a dispute concerning the Jeziorna paper factory, owned by the Natansons, emphasised exploitation to which Polish suppliers were supposed to be, arguably, subjected by the Jewish owner:

For it is a well-known fact that one of the factory owners had been the one-time author of the stock-exchange memorandum, and it had been incontrovertibly proven in the memorandum that as much as the local 'Israeli population' was marked by wisdom, sobriety, diligence and every other virtue, almost single-handedly sustaining the country's productivity, the 'native' population was a bunch of drunks and sluggardised good-for-nothings - a bunch who would not have be able to take a single step in their lives if not for the assistance and support from the "Israelites". ${ }^{13}$

Additional fuel for Rola's anti-Natansons campaign was soon supplied by controversies surrounding the ownership of a building on Jasna Street in Warsaw, which was the seat of the School of Crafts [Szkoła Rzemiosł]. In 1892, Rola alleged that Ludwik Natanson fraudulently took ownership of the building, which had been acquired with public funds, and for several years to follow, demanded that he return the property. ${ }^{14}$ At the same time, Rola - which is of the utmost interest to my subject - expressed its indignation with the fact that although the institution had been funded primarily through the means of Polish donors, Ludwik Natanson was formally appointed as the owner of the building, despite the fact, Jeleński claimed, that he "did not give a grosz" for the construction. ${ }^{15}$ Furthermore, Rola's publisher also emphasised the fact that in spite of a number of Poles belonging to the circle of donors, none other than Natanson was the only person whose merits were extolled by the contemporary press.

\footnotetext{
${ }^{11}$ Mazowiecki [Franciszek Olszewski], 'Szczerość - za szczerość (Z powodu "Memoriału Warszawskiego Komitetu Giełdowego w sprawie żydowskiej”)', Rola, no. 29, 1886: 338.

${ }^{12}$ It is worth noting, in this context, that even before establishing Rola, Jeleński had entered into direct conflict with Ludwik Natanson in relation to the 1882 census of residents of Warsaw. Natanson maintained that Jews who were born and living in Warsaw should be recorded as Poles, whereas Jeleński favoured their recording as a separate, Jewish nationality; Jagodzińska 2008: 60-61.

${ }^{13}$ Kamienny [Jan Jeleński], 'Na posterunku', Rola, no. 41, 1890: 686-687.

${ }^{14}$ Kamienny [Jan Jeleński], 'Na posterunku', Rola, no. 35, 1892: 579-580; Kamienny [Jan Jeleński], 'Na posterunku', Rola, no. 11, 1893: 173-174; 'Kronika bieżąca. Z prasy’, Rola, no. 16, 1893: 273; Kamienny [Jan Jeleński], 'Na posterunku', Rola, no. 18, 1894: 293-294; Jan Pietraszewski, 'Ciekawe rzeczy', Rola, no. 18, 1894: 290; Kamienny [Jan Jeleński], 'Na posterunku’, Rola, no. 24, 1894: 397-398.

${ }^{15}$ Kamienny [Jan Jeleński], 'Na posterunku', Rola, no. 35, 1892: 579.
} 
The circumstances offered Jeleński a pretext to a more general remark on the subject of presence of assimilated Jews in Polish public life. Jeleński derided the fact that besides the Land Credit Society, there was "not a single private institution of public use, on the board of which sat no Jews in general, and Natansons in particular." 16 According to Jeleński, the worrying over-representation of Jews in these types of institutions was caused by their "adroitness and shrewdness", which allowed them to "insinuate themselves everywhere" under the banners of "unity", "fraternity" and "assimilation", and, at the same time, resulted from a naivety of "native" Poles, who tended to give in to this sort of "emotional slogans." "17

In order to sharpen in the eyes of his readers Natanson's purported trespasses in the whole affair, Rola - in line with the Anti-Semitic stereotype it nurtured - suggested that Natanson, having grabbed the school building, would be able to dispose of it at his leisure and if such a notion was to occur to him, he would be able to transform its organisation into a "an inn, a brasserie [an alehouse] or a Jewish cheder."18

Jeleński, mobilising his readers against the Natansons, and therefore against assimilated Jews in general, resorted to extremely harsh means of persuasion, summarising the whole affair as follows:

One son of Juda mocks both the entire public opinion and its every representative. He expels a school from its own house, annihilates it, commits public damage and, ultimately, confiscates a property belonging by right to the general public, and does so with such chutzpah, fantasticality and self-confidence as if he were saying: I have gold, I have the press lip-serviced, so who can to stop me? ${ }^{19}$

According to Rola's publisher, Natanson's attempt at seizing the assets of the School of Crafts and taking control over its operations, soliciting no response from Polish donors, was "a fact emphatically characterising - oh, how emphatically! - these Jewish-assimilatory relations of ours." 20

In this light, it is unsurprising that jubilee celebrations organised in Warsaw in 1893 to honour Ludwig Natanson, as an outstanding physician and a social activist, received the following commentary from Rola: "We have it had up to here of the assimilation, whose only fruit has been a Jewification of the Polish, the proof of which, amidst a million others, is this very feast." ${ }^{21}$ Jeleński went on to ironise: "Well done! Vive le 'unity' and 'assimilation' (!), were it even to live at the expense of our - humiliation!' 22

In the same article, Jeleński, referring to the Natansons' social activity, uses the term "company", ${ }^{23}$ unequivocally suggesting that, as a matter of fact, the whole activity had nothing to do with public good, but rather was pure enterprise.

\footnotetext{
${ }^{16}$ Ibid.

${ }^{17} \mathrm{Ibid}$.

18 'Kronika bieżąca. Z prasy', Rola, no. 16, 1893: 273.

${ }^{19}$ Kamienny [Jan Jeleński], 'Na posterunku', Rola, no. 18, 1894: 294.

${ }^{20}$ Kamienny [Jan Jeleński], 'Na posterunku', Rola, no. 35, 1892: 580.

${ }^{21}$ Kamienny [Jan Jeleński], 'Na posterunku', Rola, no. 21, 1893: 359.

${ }^{22}$ Ibid.

${ }^{23}$ Ibid.
} 
Moreover, the enterprise was not defined solely in economic terms. Here we arrive at the crux of the problem: for Rola, the Jews' economic supremacy was a serious issue, but one which was related to the traditional role of the Jews in Polish society, and in European societies more broadly. Assimilation introduced a whole new area of dangers, hitherto unknown. This, precisely, was the context for Jeske-Choiński's remark on the "civilized zero", who believed in nothing, in opposition to the traditional Jew, who at least preserved the religious beliefs of his ancestors.

The liberal, frequently non-denominational, assimilated Jew so construed was the greatest threat for the Rola anti-Semites, since as much as the traditional Jewish economic exploitation was a threat to the "native" population's material existence, an expansion of the modernised, assimilated Jewry was, according to the 'Rolars', alleged to pose a deadly threat to the spiritual foundations of the workings of Polish society, to the Polish soul.

The name 'Natanson' crops up in this context as well. One of the family members entered the board of an institution organising summer camps for children, in which both Jewish and Christian children were to participate. This enraged Jeleński, who questioned what Natanson might have wanted in connection with the enterprise; he immediately gave his own answer. It is worth quoting in its entirety, since it offers a synthetic overview not only of the anti-Semitic profile of Jeleński and his milieu, but also - which is particularly pertinent here - the distinct dislike the Anti-Semites under the Rola banner exhibited towards assimilated Jews. Jeleński's revelation of Natanson's purpose read:

He wants more or less the thing the Hebrews want on the entire globe: to spoil exactly the thing that could be useful to the "goyim". When it comes to industrial, commercial or moral enterprises, the Jew always spoils, but only in the ultimate instance, in things and affairs moral, the work of degradation becomes all the more menacing as it is performed by civilised Jewry [original emphasis]. Therefore, to infect, year by year, a certain huddle of Christian children with the spirit of Judaism, especially that the Christians themselves, either too benevolent, or too liberalised, do not protest, is surely worth the Yid's trouble. ${ }^{24}$

When Henryk Natanson died in December 1895, Jan Jeleński published an article in which he summarised Natanson's work - from the proper 'Rolar' perspective. ${ }^{25}$ It is unsurprising that Jeleński returned to the stock-exchange memorandum affair and reinvoked the role played by the deceased financier and philanthropist in its formulation. Furthermore, Rola's publisher recounted opinions of the contemporary press, underlining Henryk Natanson's contributions to "the idea of the common good", such as his participation in railway construction, bank foundation, organisation of insurance societies, or his building of mines and factories. Unquestioning of these contributions, Jeleński claimed, however, that it would pose little difficulty to demonstrate that in this sort of activities, "rather extremely horizontal and egoistical goals are disguised as »the common

\footnotetext{
${ }^{24}$ Kamienny [Jan Jeleński], 'Na posterunku', Rola, no. 16, 1894: 257-258.

${ }^{25}$ Kamienny [Jan Jeleński], 'Na posterunku', Rola, no. 5, 1896: 69-70.
} 
good «," ${ }^{26}$ and that Natanson made the enormous amount of six million roubles from his supposedly social activity.

Moreover, Jeleński generalises from Natanson's case, using his example to prove that Jews' intense participation in the modernisation of Polish economy is nothing but another instalment of their economic colonisation of the "native" population. One proof of his claim were banks, which, according to Jeleński, were a straightforward continuation of traditional usury, albeit all the more perilous, as dressed up, in this incarnation, in seductive, modern robes. Jeleński wrote: "the wealthier and wiser bankers knew very well that "civilisation" and "socialisation", or "assimilation" of Jews was the most reliable and the most efficient hook for us, the Poles, terribly fond of... high-sounding slogans." 27

Further, Jeleński imputed the following manner of thinking to the modernising Jews: "Let us, then, civilise and assimilate, sounded the slogan of the Natansons and Co.'s camp; a kike will swallow ten of them, but the civilised and "assimilated" will swallow a hundred." 28 It is indispensable to draw attention to the fact that Jeleński gave the name of "the Natansons and company's camp" to his enemy formation: conclusive proof of the extent to which the leading plutocratic Warsaw family embodied, in the eyes of the 'Rolars', the evils of assimilation.

The above-quoted manner of thinking about assimilation culminated in Jeleński's blunt pronouncements, where he described slogans such as "assimilation" or "unity and fraternity with the sons of one land" as a mere halo which had long encircled the selfish activities of Jewish plutocrats "for the native community to be misled." 29

Half a year later, Rola commented on the death of Ludwik Natanson in an identical vein. Also here, his participation in preparing the stock-exchange memorandum was re-invoked, mundane and sometimes even base motivations for his public activity were alleged, and he was accused of acting solely "for his caste's sake" under the banners of assimilation. $^{30}$

The extraordinary position held by both Henryk and Ludwik Natanson in the Congress Kingdom of Poland rendered them the chief object of attacks from Jeleński's weekly. Nevertheless, also after their departure, Rola did not cease to attack the younger members of the family: they were charged with manipulation on the occasion of the competition for the Warsaw monument of Adam Mickiewicz, ${ }^{31}$ secret take-overs of Christian press titles, ${ }^{32}$ demoralisation of Polish society with publication of "free-thinking' and unprincipled brochures under the aegis of "Jewish-Heathen torch". ${ }^{33}$

Clearly, Jeleński found the rhetorical and persuasive dimension of his attacks on the Natansons to be too attractive to be abandoned after the deaths of the most

\footnotetext{
${ }^{26}$ Ibid: 70 .

${ }^{27}$ Ibid.

${ }^{28}$ Ibid.

${ }^{29}$ Kamienny [Jan Jeleński], 'Na posterunku', Rola, no. 22, 1896: 353.

${ }^{30}$ Kamienny [Jan Jeleński], 'Kronika bieżąca. Krajowa i zagraniczna', Rola, no. 25, 1896: 409.

${ }^{31}$ Kamienny [Jan Jeleński], 'Na posterunku', Rola, no. 27, 1897: 449-450.

${ }^{32}$ Kamienny [Jan Jeleński], 'Na posterunku. Zły interes!', Rola, no. 38, 1899: 620, 99; Kamienny [Jan Jeleński], 'Kronika bieżąca. Krajowa i zagraniczna', Rola, no. 50, 1899: 816-817.

${ }^{33}$ Karol Warski, 'Najnowsza Nathansoniada', Rola, no. 10, 1900: 146.
} 
outstanding and influential members of the family. In their fight against the Natansons, and, essentially, in their struggle against processes of assimilation in general, the Rola editors also resorted to peculiar linguistic devices, a strategy I am only indicating here. For instance, the term "natansonade", coined by Rola, was frequently used to describe all deeds of the loathed family, which the weekly held to be mischievous and obscure. ${ }^{34}$ Again, in their most aggressive attacks, in which Rola went beyond the sphere of facts, however subjectively interpreted, and entered into the realm of insinuation and confabulation, the Natansons were wilfully described using the fictitious name of "Panthersohns," 35 under which the readers could easily decode their corresponding prototype.

Such an identification is possible from the information and allusions scattered throughout this fictional story, as well as remarks made by Antoni Skrzynecki, who indicated that the family on whom the Pantersohns were modelled centred their business and financial operations in one institution; representing a significant financial power, they started to influence the course of social life in Poland; while remaining ardent Jews, they took pains that an opinion was formed about their deep Polish patriotism; and spreading their influence over numerous Polish environments, they were active in building the superpower of Alliance Israelite; furthermore, they became "hidden leaders of the whole nationalist, Jewish movement in Poland." ${ }^{\prime 36}$

The above-quoted remarks correspond quite precisely to ways in which Rola discussed the Natansons in its other texts; however, it should be noted that many of these remarks could as well correspond to descriptions of other rich assimilated families. Nevertheless, there is a passage in the article which dispels any doubts. It is a remark concerning the fact that the Pantersohns were editors of the "Stock Exchange memorandum", discussed above, which was drawn up mainly by Henryk Natanson. ${ }^{37}$

Making use of the convenient camouflage, Rola wrote about the Panthersohns with extreme brutality, which it might not have been able to afford in writing explicitly about the Natansons; for instance: "Like a polyp, they put down their roots in the healthy body of the nation, sneaking not only into industry and trade, but there are news of them also in the arts and the sciences - medicine, chemistry, physics and technology have in their

${ }^{34}$ Ibid.: $145-146$.

${ }^{35}$ Nieznajomy, ‘,Podskarbiowie narodu” (obrazki z natury)', part 3: 'Pantersohny', Rola, no. 25, 1891: 421-422; no. 26: 437-438; no. 27: 453-454; no. 28: 469-470; no. 29: 489-490; no. 30: 505-506; no. 31: 521-522; no. 32: 537-538. The question of the authorship remains unclear though there are certain clues that point to Antoni Skrzynecki being the Stranger ('Nieznajomy'). First Antoni Skrzynecki in Wędrowiec weekly magazine, used the pseudonym 'Ignotus', which in Latin means 'Nieznajomy' (a stranger) - the signature appearing under the first four parts of the 'Podskarbiowie narodu'. For 'Ignotus' as Skrzynecki's pseudonym see Gajkowska 1997/1998: 440-441. Second: in another work written by Antoni Skrzynecki - the novel "Warszawa 2000" (written under another pseudonym 'Werytus') - he uses the name 'Szteinpełes' which is a title of one of the series pieces and is a very unique (if at all existing) name in itself. Third: the zest and verbiage resemble that of Antoni Skrzynecki's. To learn more about his stylistics and vocabulary, see Domagalska 2004: 307-318.

${ }^{36}$ Kościesza 1910: 73.

${ }^{37}$ Ibid:: 74. 
ranks their representatives, as do sugar and paper factories as well as - the press. They are 'Israelites' working for the future of their race". ${ }^{38}$

The aversion, or even loathing, surrounding the Natansons in the pages of Rola merits special consideration. Of course, Jeleński and his milieu cherished a hearty dislike for all influential, assimilated Jews. Nonetheless, in the Natansons' case, it was exceptional. This might have resulted solely from the reality of the Warsaw family's very far-ranging influence, but it might have also been caused, in part at least, by the fact that Natansons were also active on the press market, where they came into direct conflict with Jeleński's activity. It is difficult to resolve the question conclusively. It is worthwhile, however, to end with two exceptionally pronounced statements, which appeared in Jeleński's weekly, following the deaths of Henryk and Ludwik Natanson.

According to Rola, the Natansons' activity was accompanied by "some magical hand, seemingly mysterious, which was nowhere to be seen, and yet it reached every place, especially in Warsaw dealings, giving everything up to the power and advantage of the Yid." 39 Moreover, according to Jeleński, the family of Natansons formed no less than "a covert, but efficiently operating branch of the universal union, "Alliance Israélite', whose cover, or apparent purpose, was philanthropy, and the real one the strengthening of Israel's influence and rule in all places." 40

It is therefore unsurprising that when the press began to make arguments that despite the demise of the most remarkable representatives of the family, the house of the Natansons did not perish and "steadily bore the standard of family traditions", Jeleński commented as follows:

... we know, we know by now what the "standard" smells off and what it spells out: on the one side, "assimilation", and on the other, which never faces the public: "let us make use of the gullibility and stupidity of the goyim." 41

Summarising, in 1910, Rola's achievement, one of its leading columnists, the aforementioned Antoni Skrzynecki, was pleased to recall the great anger, "indeed, rage" of the Jewish, assimilationist milieu, caused by the publication of their anti-Natansons lampoon on the Panthersons, which, according to Skrzynecki, tore down the legend of "exceptional commitment to public life and respectability of a certain family of financiers, attempting to create, on Warsaw territory, a kind of a house of Rothschild." ${ }^{2} 2$ This remark, made after many years, provides a perfect summary of the nature of Rola's longstanding campaign against the Natansons, unwaveringly treated by Jan Jeleński and his collaborators as dangerous enemies, as an embodiment of the evils of assimilation which Rola combated fiercely for a quarter of a century.

\footnotetext{
${ }^{38}$ N. [Nieznajomy], ‘»Podskarbiowie narodu« (Obrazki i typy)’, part 5: ‘Szteinpełesy’, Rola, no. 1, 1893: 1.

${ }^{39}$ Kamienny [Jan Jeleński], 'Kronika bieżąca. Krajowa i zagraniczna', Rola, no. 25, 1896: 409.

${ }^{40} \mathrm{Ibid}$.

${ }^{41}$ Kamienny [Jan Jeleński], 'Na posterunku', Rola, no. 29, 1896: 470.

${ }^{42}$ Kościesza 1910: 73.
} 


\section{BIBLIOGRAPHY}

\section{Press}

Rola $1883-1912$.

Niwa 1886, no. 276.

\section{Secondary literature}

Domagalska, M. (2004), Zabawa w chowanego. Antoni Skrzynecki wobec Żydów, in: G. Borkowska, M. Rudkowska (eds.), Kwestia żydowska w XIX wieku. Spory o tożsamość Polaków, Warszawa: 307-318.

Domagalska, M. (2015), Zatrute ziarno. Proza antysemicka na tamach „Roli” (1883-1912), Warszawa.

Eisenbach, A. (1983), Raport o położeniu i strukturze ludności żydowskiej w Królestwie Kongresowym w latach osiemdziesiątych XIX wieku, in: idem, $Z$ dziejów ludności żydowskiej w Polsce w XVIII i XIX wieku. Studia i szkice, Warszawa: 254-302.

Friedrich, A. (2008), Bolestaw Prus wobec kwestii żydowskiej, Gdańsk.

Gajkowska, C. (1997/1998), Skrzynecki Antoni, in: Polski Stownik Biograficzny, vol. 38, Warszawa: $440-441$.

Ignotus (2008) [Adolf Peretz], Finansjera warszawska (1870-1925) (Z osobistych wspomnień), Warszawa.

Jagodzińska, A. (2008), Pomiędzy. Akulturacja Żydów Warszawy w drugiej połowie XIX wieku, Wrocław. Jaszczuk, A. (1986), Spór pozytywistów z konserwatystami o przyszłość Polski. 1870-1903, Warszawa. Kościesza, Z. (1910), [Antoni Skrzynecki], 'Ćwierćwiecze walki', in: Ćwierćwiecze walki. Księga pamiatkowa ,Roli”, Warszawa: 1-90.

Moszyński, M. (2017), Antysemityzm w Królestwie Polskim. Narodziny nowoczesnej ideologii antyżydowskiej (1864-1914), Poznań.

Szweykowski, Z. (1960), Przypisy, in: B. Prus, Kroniki, vol. 9, Warszawa: 331-567.

Weeks, Th.R. (2006), From Assimilation to Antisemitism: The "Jewish Question" in Poland 18501914, DeKalb, IL.

Zaleski, A. (1971), Towarzystwo warszawskie. Listy do przyjaciótki przez Baronowa XYZ, ed. R. Kołodziejczyk, Warszawa. 